\title{
IAMJ
}

INTERNATIONAL

AYURVEDIC

MEDICAL JOURNAL

\section{UNDERSTANDING OF CONCEPT OF UDAKA IN AYURVEDA \& MODERN PERSPECTIVE: A REVIEW}

\author{
Babaita Sharma $^{1}$ A. K. Sonkar ${ }^{2}$, Sunil Mewade ${ }^{3}$ \\ ${ }^{1}$ Associate Professor, Dept. of Kriya Sharir, Pt. Khushilal Sharma Govt. Ayurveda College \& Institute, Bhopal, \\ MP, India \\ ${ }^{3}$ Ex. Professor \& Head, Department of Kriya Sharir, Govt Post Graduate Ayurveda College and Hospital, \\ Varanasi (U.P.), India \\ ${ }^{3}$ Assistant Professor, Dept. of Kriya Sharir, Pt. Shiv Shaktilal Sharma Ayurveda Medical College Ratlam (M.P.), \\ India
}

Email: drbabita.sharma@rediffmail.com

\section{https://doi.org/10.46607/iamj1908082020}

(Published online: August 2020)

Open Access

(C) International Ayurvedic Medical Journal, India 2020

Article Received: 08/07/2020 - Peer Reviewed: 29/07/2020 - Accepted for Publication: 29/07/2020

(D) Check for updates

\section{ABSTRACT}

This review attempts to provide some concept about physiological aspect of Udaka in Ayurveda \& its correlation with body water in modern perspective. Water is physiological basis of hydration \& forms approximately $45-75 \%$ of total body weight (50-55\% in female while 60- 65\% in male) as total body water (TBW). Normal volume of water in body is highly essential to carry out all biological processes properly so is highly indispensable for life. In Ayurveda Udaka term is used to represent body water. Its normal quantity mentioned is ten Anjali measured by one's own. It does not simply represent water in the body which we intake but signifies various form of body fluids like water fraction of Dhatus (Rasa, Rakta, Mamsa, Meda, Majja, Shukra), Upadhatus (Stanya and Vasa) and Malas (Mutra, Sweda and Dravyansh of Purish). It can be correlated with the concept of total body water in modern physiology.

Keywords: Udaka, Ap, Apya Dravya, Rasa, Rakta, Anjali Pramana. 


\section{INTRODUCTION}

Water is the major constituent of our body, forming approx. $60 \%$ of our body weight ${ }^{1}$. A man weighing about $70 \mathrm{~kg}$ has about $40 \mathrm{~L}$ total body water distributed in two compartments: Extracellular \& intracellu$\operatorname{lar}^{2}$. Proper hydration inside the body is very essential for normal functioning of the cells. That means water is a very crucial element for health \& life.

Ayurveda signifies $A p$ as one of the five basic elements (Panchmahabhuta), forming a part of physical constitution of all living beings, performing several important actions \& representing group of body fluids 3. All bodily elements having predominance of $A p$ Mahabhuta are mentioned as Apya Dravyas eg. Rasa, Rakta, Kleda, Vasa, Kapha, Pitta, Mutra and Sweda. ${ }^{4}$ Udaka represents the physiological aspect of $A p M a$ habhuta in the body. Unfortunately, no research work has been done to explore the concept of such an important physiological factor described in Ayurveda classic texts as Udaka so far so this is the need of hour to review the concept of Udaka and its physiological significance. On the other hand, in contemporary science physiological aspect of total body water including its systematic classification in different compartments like ECF and ICF is available in detail so the aim of this article is to explore the physiological aspect of $U d a k a \&$ its modern perspective.
Review of Literature: $A p$ exhibits important attributes viz: Rasa, Guru, Sneha, Sheeta, Drava, Manda, Mrudu, Pichchila, \& being the constitutional element of the body performs several important actions in the body like Rasana, Snehana, Bandhana, Syandana, Kledana, Mardavata, Mraduta, and Hrallada etc. representing group of body liquids ${ }^{5}$. The verbal meaning of Udaka is water / aqueous element of body ${ }^{6}$. In Ayurveda Udaka term is used to represent body water present in both compartments (extra and intra cellular).

It's normal quantity mentioned is ten Anjali. ${ }^{7}$ Anjali Pramana also known as Kudav or Ardhasharava, is a type of Druvaya Mana ${ }^{8}$, a method to measure liquid (\& semiliquid) Sharir Bhavas ${ }^{9}$ filled in the bowl like shape made by joining both our palms with little fingers of both the hands in such a way that one may hold maximum volume of a liquid. It is based upon one's own Anjali (Svena Anjali Pramanena), so is very specific to a person $\&$ vary individual to individual, showing personalized approach of measurement of bodily elements \& shows the measurement of Sama Dhatu (body tissue in physiological limit) of the individual whose Anjali Pramana is being measured ${ }^{10}$.

Table 1: Anjali Pramana of Bodily Elements According to Charaka ${ }^{9}$

\begin{tabular}{|l|l|l|}
\hline S. No. & Bodily Element & Anjali Pramana \\
\hline 1. & Udaka & 10 \\
\hline 2. & Ahararasa /Rasa & 09 \\
\hline 3. & Rakta / Shonita & 08 \\
\hline 4. & Purisha & 07 \\
\hline 5. & Kapha & 06 \\
\hline 6. & Pitta & 05 \\
\hline 7. & Mutra & 04 \\
\hline 8. & Vasa & 03 \\
\hline 9. & Meda & 02 \\
\hline 10. & Majja & 01 \\
\hline 11. & Shukra, Mastishka, Oja (Apara) & $1 / 2$ \\
\hline
\end{tabular}


Table 2: Anjali Pramana of Bodily Elements According to Vagbhatta ${ }^{11}$

\begin{tabular}{|l|l|l|}
\hline S. No. & Bodily Element & Anjali Pramana \\
\hline 1. & Majja & 01 \\
\hline 2. & Meda & 02 \\
\hline 3. & Vasa & 03 \\
\hline 4. & Mutra & 04 \\
\hline 5. & Pitta & 05 \\
\hline 6. & Shleshma & 06 \\
\hline 7. & Shakrit & 07 \\
\hline 8. & Rakta & 08 \\
\hline 9. & Rasa & 09 \\
\hline 10. & Jala & 10 \\
\hline 11. & Retas, Mastishka, Oja & $1 / 2$ \\
\hline 12. & Stanya & 02 \\
\hline 13. & Raja & 04 \\
\hline
\end{tabular}

Paniya, Salil, Neer, Kilal, Jala, Ambu, Ap, Var, Vari, Toya, Paya, Payas, Jeeravan, Ambha, Arana, Amruta and Ghanarasa are some important synonyms of Udaka ${ }^{12}$.

As mentioned in Charaka Samhita, following liquid elements all together are called Udaka ${ }^{13}$ : when in excess excretes out as watery feces as in Atisar, which excretes out the body through urine, which is a part of Rakta Dhatu, which is present as moisture in all Dhatus like Mamsa etc., which is present all over the body specially in the outermost layer of Twacha (Avbhasini), preventing it from desiccation or as Lasika in between the seven layers of Twacha, oozing out from Vrana in skin \& is excreted out as Sweda from skin \& the areas surrounding hair follicles. While describing symptoms of Atisara in Madhav Nidana, it is said that watery element of the body get increased, diminishes digestive functions and under the influence of Vata moves downward and get mixed with fecal matter in Pakwashaya producing frequent elimination of feces. ${ }^{14}$

Body Fluids are liquid part forms $2 / 3$ part of the whole body \& approx. $45-75 \%$ of total body weight. (In adult Female: $50-55 \%$ while in adult male: 60 $65 \%) \&$ termed as total body water (TBW). ${ }^{2}$

Table 3: Distribution of body fluids ${ }^{15}$

\section{Intracellular Fluid}

It is found inside the cells.

It forms approx $55 \%$ of total body fluids \& $40 \%$ of total body weight. (approx.22 L of $40 \mathrm{~L}$ )

\section{Extracellular Fluid}

It is found outside the cells.

It forms approx $45 \%$ of total body fluids \& $20 \%$ of total body weight. (approx.18 L of $40 \mathrm{~L}$ )
Extracellular compartment of body fluids includs:

- Blood plasma

- Lymph and interstitial fluid

- Mesenchymal tissue fluids:

a) Fluid found in bones

b) Fluid found in fibrous connective tissues

- Transcellular tissue fluids

Blood Plasma: It is the liquid part of blood. It comprises of $25 \%$ of ECF and $5 \%$ of body weight. Total volume of blood in an average adult male is $5 \mathrm{~L}$ and plasma is approx $3.5 \mathrm{~L}$.

Interstitial Fluid: It is the main component of extracellular body fluids, $12 \mathrm{~L}$ of the $40 \mathrm{~L}$ total body water. It forms the internal environment of the body in which cells are bathed. It fills the spaces between the cells of the body except fluid within the blood and lymph. It is formed by filtration through the blood capillaries. Its composition is almost like blood plasma, but it con- 
tains less protein component as compared to blood plasma. It may also call tissue fluid, since it surrounds the cells of the tissue. It provides the medium to supply substances to the cells and removal of metabolic wastes from the cells. It also serves as a mean of communication between the cells (intra-cellular communication).

Mesenchymal (Tissue) Fluid: It is found in the tissue originated from mesenchyma and forms about $6 \%$ of total body water (TBW).

Transcellular Fluid: It forms the smallest part of ECF compartment (1.5\%) of total body water and presents between epithelial lined spaces. It is separated from other compartments of ECF by cell membranes (cellular barriers) and is formed from transport activities of the cells like secretion of secretory and grandular cells, e.g. cerebrospinal fluid, pericardial fluid, pleural fluid, peritoneal fluid, synovial fluid, intraocular fluid, lacrimal fluid, luminal fluids of gut, thyroid and chochlea $\&$ fluid in urinary tract etc. ${ }^{15}$

\section{Material and Method}

All available relevant texts and authentic publications from Ayurveda as well as contemporary literature has been compiled and analyzed thoroughly to review the physiological concept of Udaka \& its correlation in modern perspective.

\section{DISCUSSION}

Udaka is a specific term used to denote body water in Ayurveda. It is an important and major constituent, representing Ap Mahabhuta in the body, exhibiting properties like cohesion and viscosity, which make it capable to bind things together and to keep them moving as owing the attributes like Sara, Drava, Chala, Snigdha, Pichhila 5 . Also, it serves as the unique solvent capable of dissolving most of the biomolecules.
Normal volume of water in body is highly essential to carry out all biological processes properly so is highly indispensible for life.

Charaka presented a unique concept of normal volume of liquid and non liquid bodily elements (Udaka, Rasa, Rakta, Purisha, Kapha, Pitta, Mutra, Meda, Majja, Vasa and Shukra etc.) in Anjali Pramana, showing interrelation among them \& described the Anjali Pramana of Udaka vary first, showing it as the most important and the most abundant constituent of the body with ten Anjali in volume. It can be correlated with the concept of total body water in modern physiology. Next comes Rasa Dhatu, which is freely circulating body fluid with nine Anjali in quantity, then comes Rakta, which is again a liquid Dhatu, derived from Rasa and confined to its channels, Dhamani only and does not come out of it. Its normal volume is eight Anjali. Both are liquid Dhatus having predominance of Apa Mahabhuta, but Rasa has predominance of Ap Mahabhuta only while Rakta has dominance of $A p$ and $T e j$ both that means Apya portion of Rasa Dhatu has more Ap while Apya portion of Rakta has $A p$ with Tej also. ${ }^{16}$

Udaka is not simply represents water in the body which we intake but signifies various form of body fluids like water fraction of Dhatus (Rasa, Rakta, Mamsa, Meda, Majja, Shukra), Upadhatus (Stanya and Vasa) and Malas (Mutra, Sweda and Dravyansh of Purish), which vary from each other owing to their specific solute composition depending upon the part or organ of the body which contain it, attributing them specificity in their properties \& functions. But one thing is common in all that water/Udaka is serving as the liquid medium in all of them. Finally, the term Udaka signifies the liquid fraction of all JaliyalApya elements of the body:

Table 4: Apya Bodily Elements

\begin{tabular}{|l|l|l|}
\hline S.No. & Apya Dravyas & Apya Bodily Elements \\
\hline 1. & Apya Dhatu & Rasa, Rakta, Meda, Majja and Shukra \\
\hline 2. & Apya Upadhatu & Stanya, Vasa \\
\hline 3. & Apya Mala & Kapha, Pitta, Mutra, Sweda \\
\hline 4. & Other Apya Dravya & kleda, Lasika, Rakta Rasa, \\
\hline
\end{tabular}


Anguli \& Anjali Mana are described to measure Sharira Bhavas, Anjali Pramana is used to measure liquid body tissues so belongs to Dravaya mean of measurement ${ }^{8} . \&$ it is stated that measure should be taken as one's own Anjali (Svena Anjali Pramanena), which shows that quantity of Udaka varies with indi- vidual to individual so is very personalized $\&$ individualistic $^{16}$. In classical texts of Ayurveda several methods of measurement of ancient time are described. One of these methods is based on geographical regions of that time including two-way measurements viz: Magadha \& Kalinga Mana.

Table 5: Comparison between Anjali Pramana by Magadha \& Kalinga Mana ${ }^{17}$

\section{Magadha Mana}

One Kudav equals to one Anjali

\section{Kalinga Mana}

One Kudav equals to two Prastri equals to two Prastri equals to two Pala
It can be concluded that one Anjali measurement is taken equivalent to one Kudav (four Pala) ${ }^{18}$.

Furthermore, it is mentioned that this measurement is prescribed for dry Aushadh Dravyas only. For measuring liquid substances, it is advised to consider the measurement just double to that of dry ones ${ }^{19}$. (4 Pala $=1$ Kudav or Anjali while for liquid it is taken just double that means one Anjali may be equal to 8 Pala). One Anjali /Kudav equals to four Pala equal to approx.192 gms ${ }^{17}$.

Sharangdhara has defined Kudav measurement equals to a volume of liquid filled in a cylindrical cup shaped pot of mud, wood or metal of 4 Angul in length, width and height each ${ }^{20 .}$

Here one Angul equals to $6.17 \mathrm{~cm}$ approx. so one Kudav equals to $6.17^{3}=235 \mathrm{~cm}^{3}$, it means volume of a pot with 1 Kudav measurement should be $235 \mathrm{~cm}^{3}$, which may contain approx.400-500 $\mathrm{ml}$ of non liquid and $800-1000 \mathrm{ml}$. of liquid substances. In this way 10 Anjali Udaka may equals to $10 \mathrm{~L}^{21}$

Also, it has been mentioned that the volume of bodily elements regularly varies in physiological limits showing unstability in their measurements ${ }^{22}$ as well as with changing eras due to changes in the size of body $\&$ body parts so cannot be measure accurately. ${ }^{23}$

As in modern concept all body fluids are predominantly comprised of water as the major constituent eg. blood has 55\% while plasma and lymph contain $99 \%$ water in their composition ${ }^{2}$. Although in our classical texts, no any similar thought of measurement of water content in composition of a particular Apya Dravya has not been observed, but it is assumed that when Anjali measurements of all Apya Dravys of the body are taken in consideration and sum up, the total measurement of Udaka might be near to the measurement given in modern physiology that is $40 \mathrm{~L}$. moreover, it's very difficult to assess the accurate volume of Udaka in the body in the review study so it is further recommended to carry our any observational study to assess the measurement of Udaka in the body to justify its comparison with body water and body fluids in modern perspective.

\section{CONCLUSION}

Udaka is a specific term used to denote body water in Ayurveda. It is an important and major constituent, representing Ap Mahabhuta in the body \& includes various form of body fluids like water fraction of Dhatus (Rasa, Rakta, Mamsa, Meda, Majja, Shukra), Upadhatus (Stanya and Vasa) and Malas (Mutra, Sweda and Dravyansh of Purisha). These Apya Dravyas vary from each other owing to their specific solute composition, which make them specific in their properties and capable of performing their respective functions also but one thing is common in all, that water/Udaka serves as the liquid medium in all of them \& can be correlated with the concept of total body water in modern physiology.

Rasa serves as the liquid Dhatu of the body, differentiate from Udaka as having various dissolved nutrients. Its Poshak part serves as fluid medium of circulation and provides fluidity to circulating Rakta also. Along with Rakta \& Lasika, it may resemble ECF (extra cellular fluid) including blood plasma, lymph and interstitial fluid while Poshya Rasa Dhatu may correspond with intracellular \& tissue fluid (ECF). Kleda 
signifies internal body moisture required for smooth functioning of the Dhatus but when in excess serves as Dushya in pathogenesis of various disorders.

\section{REFERENCES}

1. Water as an essential Nutrient, E. Jequier \& F. Constant, European Journal of clinical Nutrition, published 2/9/2009, Online Article

2. Sembulingam K \& Sembulingam P, Essentials of Medical Physiology, New Delhi, Jaypee Brothers Medical Publishers (p) Ltd, $5^{\text {th }}$ Edition 2010, p.33-34.

3. Desai R R, Ayurvediya Kriya Sharir, Allahabad: Shri Baidhyanath Ayurved Bhavan Ltd., Edition 2007, p. 97.

4. Sharma P V, Susruta Samhita (English translation), Vol. 2: Varanasi Chaukhamba Vishvabharati, Edition 2013, p .124.

5. (a) Kushwaha HS, Charaka Samhita, Vol. 1, Varanasi: Chaukhamba Orientalia, Edition 2011, p.792.

6. (b) Acharya JT, Charaka Samhita, Varanasi: Chaukhamba Sanskrit Sansthan, $4^{\text {th }}$ Edition 1994, p. 138.

7. Sanskrit Dictionary.com, books google.co.in

8. Kushwaha HS, Charaka Samhita, Vol. 1, Varanasi: Chaukhamba Orientalia, Edition 2011, p.849.

9. Acharya M S, Abhinav Bhaishajya Kalpana Vigyan, Varanasi: Chaukhamba Surbharti Prakashan, Reprint Edition 2005, p.41.

10. Acharya JT, Charaka Samhita with Ayurveda Deepika commntary of Chakrapani Datta Varanasi: Chaukhamba Orientaliya, Reprint Edition 2013, p. 339.

11. Vidhyasagar P S, Sharangdhara Samhita (Purvakhanda), Dipika \& Gudharth Dipika, Varanasi: Chaukhamba Surbharati prakashan,Reprint Edition 2013,p.8.

12. Murthy KRS, Ashtang Hridaya, Varanasi: Chaukhamba Krishnadas Academy, Reprint Edition 1, 2016, p.412.

13. Pandey K, Singh AN, Gunaratnamala, Varanasi: Chaukhamba Sanskrit Sansthan, $1^{\text {st }}$ Edition VS 2062, p.501.

14. Sharma PV, Charak Samhita (Text with English translation), Varanasi: Chaukhamba Orientalia, $3^{\text {rd }}$ Edition 1998, p.459-60.

15. Murthy KR, Madhava Nidana, Varanasi: Chukhambha Orientalia, $8^{\text {th }}$ Edition 2007, p.161.

16. Brinkman J E, Dorius B, Sharma S, Physiology, Body Fluids,Last updated May 24,2020. Treasure Island (FL), Stat Pearls Publishing, Jan.2020, www.ncbi.nlm.nih.gov>books.
17. Dhargalkar ND, Sharira Kriya Vidnana, Vol.2, Chowkhamba Sanskrit Series Office, $3{ }^{\text {rd }}$ Edition 2011, p.351.

18. Understanding of Anjali Pramana Sourav Ballar et al, WJPS, ISSN-2278-4353, Vol.7, Issue 12.p, 533-536.

19. Shrivastava Shailaja, Sharangdhara Samhita, (Purva Khanda), with Jiwanprada Hindi Commentary, Varanasi: Chaukhamba Orientalia, Reprint Edition 2011, p.10.

20. Charak Samhita (with Vidhyotini Hindi Commentary) Varanasi: Chukhambha Bharati Academy, Reprint 2015, p.913.

21. Shrivastava Shailaja, Sharangdhara Samhita, (Purva Khanda), with Jiwanprada Hindi Commentary, Varanasi: Chaukhamba Orientalia, Reprint Edition 2011, p.9.

22. Sharma H L, Shastri P,Sharangdhar Samhita,by Sharangdhara Acharya, Part 1,Varanasi:Chaukhamba Orientaliya, Edition 2018,p. 9.

23. Acharya J T, Sushruta Samhita with nibandhasamgraha commentary of Dalhana, Varanasi: Chaukhamba Sanskrit Samsthan, Reprint Edition 2010, p.74.

24. (a.) Shastri Kashinath, Charaka Samhita of Agnivesha,with Commentary of Chakrapani \& Gangadhar, Varanasi; Chaukhamba Sanskrit Samsthan,Reprint Edition 2006,p.697.

25. (b.) Kashyap Samhita of Vruuddha Jeevaka, Edited by Sharma Hemraj, Varanasi: Chaukhamba Sanskrit Samsthan, Reprint Edition, 2006, p.78.

\section{Source of Support: Nil \\ Conflict of Interest: None Declared}

How to cite this URL: Babaita Sharma et al: Understanding Of Concept Of Udaka In Ayurveda \& Modern Perspective: A Review. International Ayurvedic Medical Journal \{online\} 2020 \{cited August, 2020\} Available from: http://www.iamj.in/posts/images/upload/4157 4162.pdf 